\title{
Impact of Agricultural Credit on Cereal Productivity: Case Study of District Sargodha, Punjab Pakistan
}

\author{
Maria Shabir'1, Kashif Amin², Awis Muhammad², Junaid Ahmad² \\ ${ }^{1}$ University of Agriculture Faisalabad, Faisalabad, Pakistan \\ ${ }^{2}$ North China Electric Power University, Beijing, China \\ Email: Mariashabbir437@gmail.com, Kashifrana402@gmail.com, solangijunaid420@gmail.com, Awaisbhatti80@yahoo.com
}

How to cite this paper: Shabir, M., Amin, K., Muhammad, A., \& Ahmad, J. (2020). Impact of Agricultural Credit on Cereal Productivity: Case Study of District Sargodha, Punjab Pakistan. Theoretical Economics Letters, 10, 481-487.

https://doi.org/10.4236/tel.2020.103030

Received: March 13, 2020

Accepted: May 19, 2020

Published: May 22, 2020

Copyright $\odot 2020$ by author(s) and Scientific Research Publishing Inc. This work is licensed under the Creative Commons Attribution International License (CC BY 4.0).

http://creativecommons.org/licenses/by/4.0/

\begin{abstract}
Agriculture is a major sector of Pakistan's economy, as it contributes significantly to Pakistan's economy by providing GDP, jobs, and export income. In recent decades, the financing needs of farmers have increased rapidly due to a restructuring of the agricultural sector. Credit is seen as an important factor in raising farmers' production and profits. The current study seeks to examine the impact of credit on the productivity of cereal in the Sargodha District. In addition, the study examines farmers' objective to receive loans and major credit sources in the Sargodha district. This study is based on the primary data from the 8 villages in Sargodha-Punjab district, Pakistan collected in 2018. The area was divided into four zones, and from each zone, two villages were chosen. The same number of beneficiaries, i.e. ten each, from each village was selected. The sample size, therefore, referred to 160 farmers. The data were analyzed using the Cobb Douglas Production Function (CDPF). The results of the study show that credit has a positive effect on the productivity of wheat. Research has shown that only $30 \%$ of the credit users use loan to buy seeds and fertilizers and $70 \%$ use loan for other purposes, such as marriages and ceremonies and farmland and tractor buying, among others. Similarly, Zarai Tarqiati Bank Limited (ZTBL) loans 80 percent of credit customers. It is recommended that the financial institution expands the credit facilities exclusively for agricultural farmers. Credit restrictions should also be reduced plausibly so that smallholders can easily obtain loans.
\end{abstract}

\section{Keywords}

Agricultural Credit, Cobb Douglas Production Function, Crop Productivity, 
Cereal

\section{Introduction}

Agriculture is the Pakistan's largest sector with significant effects on rural socio-economic conditions. As the dominant segment, it contributes $21.4 \%$ of the GDP, employs $45 \%$ of the country's workforce and helps other economic sectors develop (GOP, 2018a, 2018b). For economic development, an increase in people's living standards and the reduction of poverty in Pakistan's rural zones, sustainable agricultural development is required. For various farm operations in the field of agriculture, loans are available. Modern technologies, buying fertilizers and improved seeds are necessary for time for credit. Agricultural lending is, therefore, a necessary part of modernization in the agricultural sector. In general, developing countries have set up structured institutions to channel loans to small-scale farmers (Machete, 2004). Farmers' credit needs have grown rapidly in recent decades as a result of modernizations in agriculture. The agricultural loan system in Pakistan includes informal and formal lending sources. Informal sources are friends, family members, commission agents, dealers and private lenders. At present, financial institutions like Zarai Taraqiati Bank Limited (ZTBL), commercial banks, and co-operation companies are the largest formal source of loans. Farmers' credit needs have increased rapidly over recent decades as a result of modernization in the agriculture sector (Jan et al., 2012). ZTBL provided loans to Pakistan's agriculture industry. Credit is a key factor in enhancing rural poor welfare through the ease of use, which decreases its vulnerability in short-term revenues. It also increases the productive capacity of poor farmers by financing improvements in their physical and human resources (Okurut et al., 2004).

Bashir et al. (2010) having studied the effect of credit on Lahore District wheat productivity using the Cobb Douglas Production Method, the credit has a positive influence on wheat productivity. Sebopetji and Belete (2009) were noted that gender and agriculture have considerable positive effects on the decision of farmers to use credit. It was proposed that a loan support scheme, targeted at vulnerable and established farmers, should be implemented so that production is increased.

\section{Materials and Methods}

\subsection{Research Location and Data}

The research is based on Primary data from four Tehsils known as "zones" in Sargodha District in Punjab Province of Pakistan collected in 2018. In the four areas Tehsil Bhera, Tehsil Bhalwal, Thehsil Kot Mom and Tehsil Sargodha were included. Two villages were randomly selected from each zone, as indicated in the parenthesis. 10 lenders and 10 non-lenders have been randomly selected from each village. The overall sample size was 160 households, comprising half lenders and half non-lenders (Figure 1). 


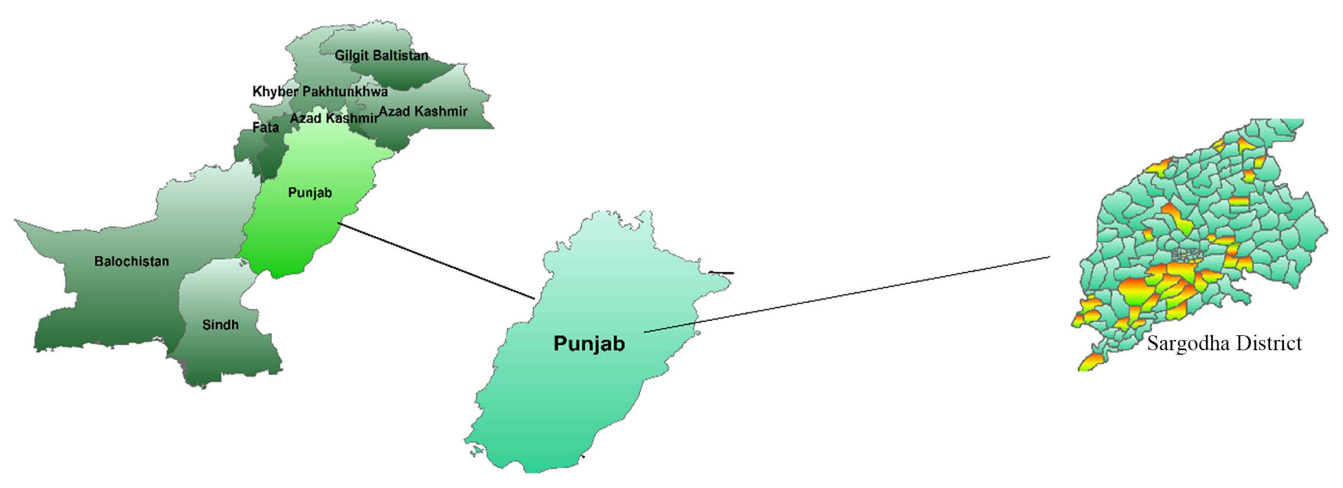

Figure 1. Map of study area $32^{\circ} 5^{\prime} 11^{\prime \prime}$ North, $72^{\circ} 40^{\prime} 16^{\prime \prime}$ East.

\subsection{Analytical Technique}

This analysis was carried out using the Cobb Douglas Production Function (CDPF). It is used because of some of its advantages and provides the computation and consistency characteristics; its reproduced capabilities and flexibilities (Bhanumurthy, 2002). The data sample is a logarithmic vector and is analyzed in a linear standard regression form. In order to analyze the effect of credit on wheat production, the following functional type was applied to the data set.

Cobb-Douglas production is of the form:

$$
Y=A X_{1} \beta 1 X_{2} \beta 2 X_{3} \beta 3 X_{4} \beta 4 X_{5} \beta 5
$$

Taking the natural log of Equation (1) and considering the case of five explanatory variables, the equation.

(1) converts to the following form:

$$
\ln Y=\beta+\beta \ln x_{1}+\beta \ln x_{2}+\beta \ln x_{3}+\beta \ln x_{4}+\beta x_{5}+\mu \ldots
$$

where,

$$
\begin{aligned}
& \beta=\text { Natural } \log \text { of } \mathrm{A}=\text { Intercept; } \\
& \ln Y=\text { Natural } \log \text { of the yield of wheat (kg/ha); } \\
& \ln x 1=\text { Natural } \log \text { of manure cost (Rupees } / \mathrm{ha}) ; \\
& \ln x 2=\text { Natural } \log \text { of irrigation cost (Rupees } / \mathrm{ha}) ; \\
& \ln x 3=\text { Natural } \log \text { of plant shield cost (Rupees } / \mathrm{ha}) \ln X 4=\text { Natural log of land } \\
& \text { preparation cost (Rupees/ha) } x 5=\text { Dummy variable representing credit users; }
\end{aligned}
$$

( 1 for credit user and 0 alternatively).

Ronald Fisher firstly gave the concept of Hypothesis testing. Testing of hypotheses is a statistical approach used in scientific judgments using experimental evidence. In theory, the testing of hypotheses is an assumption we take on the population parameter. One the basis of alpha value we accept or reject or Null Hypothesis. However, in order to examine the effect on increased productivity of wheat cultivation in Sargodha District, Pakistan, the following hypothesis has been generated by studying the agricultural credit literature.

$\mathrm{H}_{0}$ : Credit has no impact on Cereal productivity.

$\mathrm{H}_{1}$ : The effect of credit on the cereal production is significantly Positive. 


\section{Results and Discussion}

Results as shown in Figure 2 demonstrate that $40 \%$ of the credit users had 10 20 years of agricultural experience, compared to $32.5 \%$ of those with an experience range of 21 - 30. Results show that only $2.5 \%$ of credit users have a 50 to the 60-year farming background.

Figure 3 also reveals that $35 \%$ of non-credit users are farmers with 10 to 20 years' farming experience and that the same percentage for non-credit users of 21 - 30 years' farming experience is $32.5 \%$. Figure 2 also reveals that $35 \%$ of non-credit users are farmers with 10 to 20 years' farming experience and that the same percentage for non-credit users of 21 - 30 years' farming experience is $32.5 \%$.

Figure 4 shows that $80 \%$ of loan recipients lent at the country's largest agricultural lending facility, i.e. Zarai Tariaqiati Bank Limited (ZTBL). Just 2.5\% of the respondents took loans from commission agents. Another $12.5 \%$ of those who met borrowed from friends and 5\% from other sources borrowed. This shows that both formal and informal credit sources benefited local residents, however, the region was dominated by formal credit source (ZTBL).

\section{Farming Experience(Credit Users)}

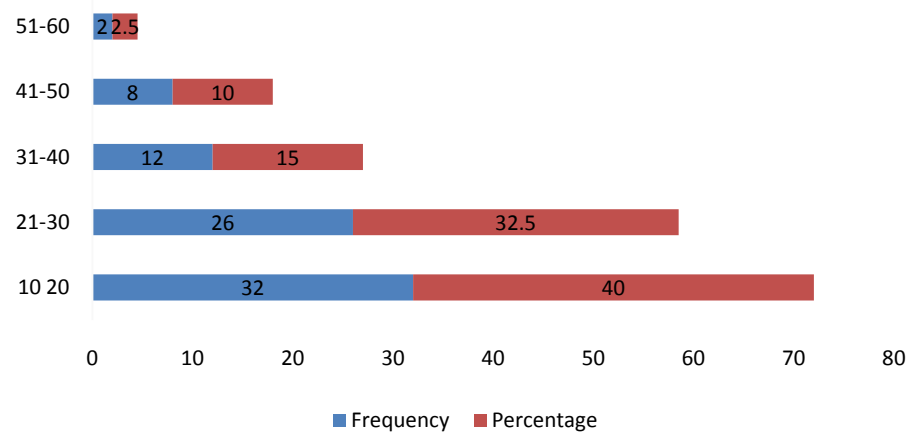

Figure 2. Frequency distribution based on Farming experience for credit users. Source: Field Data, 2018.

Farming Experience(non credit users)

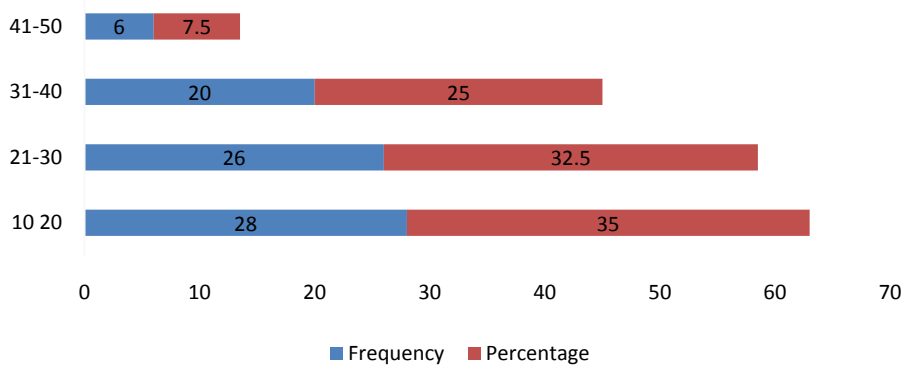

Figure 3. Frequency distribution based on-farm experience by non-credit users. Source: Field Data, 2018. 


\section{CREDIT SOURCES}

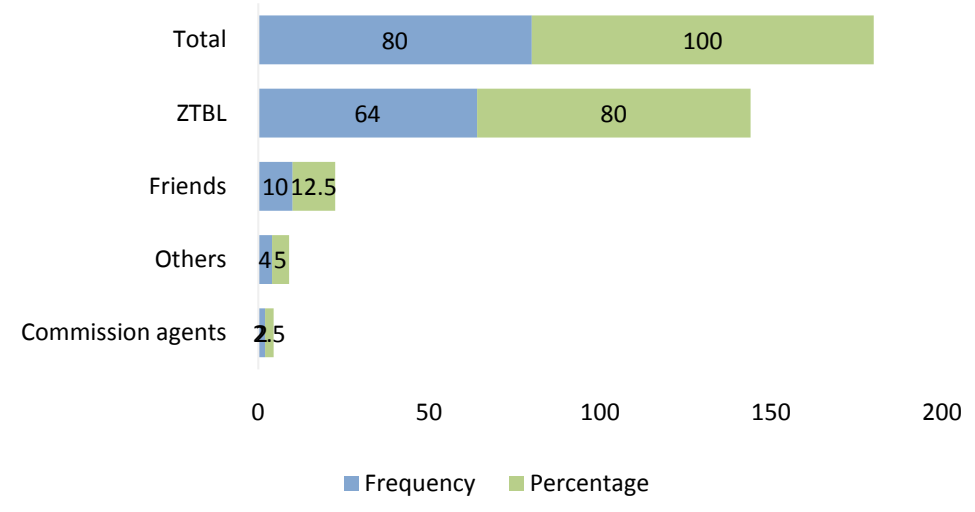

Figure 4. Credit usage frequency distribution based on credit source. Source: Field Data, 2018.

The percentage distribution of credit received for the purpose of the loan is show in Figure 5. Credit loans covered 2.5\% of farmers receiving loans for land solely for farming purposes. Just $2.5 \%$ of farmers purchased a tractor loan, while those of the same age purchased a tube loan. Likewise, $25 \%$ of the farming export loans were taken. Nearly $30 \%$ of borrowers used loans for inputs such as seeds and fertilizers.

\section{Results of the Cobb Douglas Production Function}

The results of the regression analysis are shown in Table 1. The coefficients were determined using the Cobb Douglas production function (CDPF). It means a wheat yield of 10.18 if the input is not used. The intercept is 10.18. The fertilizer coefficient is -0.09 , which indicates that 1 percent use of fertilizer is likely to cause a 0.09 percent decrease in the amount of wheat, which is a negative sign that it is a coefficient. The irrigation coefficient is 0.01 , which indicates that the yield increases by $0.01 \%$ by $1 \%$. The findings are comparable to the estimates of Bashir et al. (2010), Iqbal et al. (2003) as well as the positive impact of credit on wheat production, using CDPF for assessment.

The main concern of the analysis is the effect of credit on wheat production and the projected credit factor is 0.05 which indicates that the credit usage generates growth of 5 percent, because this coefficient of credit is semi-elastic. A significant outcome of the result is that sufficient use of credit and therefore increased wheat production would lead to higher income leading to poverty reduction in rural areas. Similarly, an increase of 1 percent in plant protection would increase wheat yield by 0.16 percent. The preparation coefficient of the soil is 0.01 , which means that if the preparation of the soil is increased by $1 \%$, production would increase by $0.1 \%$. All the variables affected the production of wheat significantly with the exception of irrigation and preparation. The sample sites had an average wheat yield of $3560 \mathrm{~kg} / \mathrm{ha}$. 


\section{Utilization of Credit}

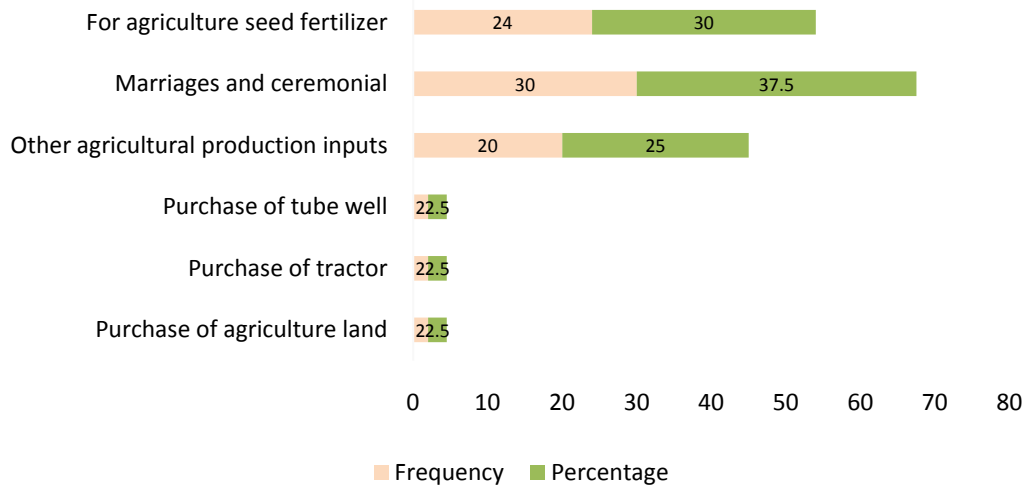

Figure 5. Card users' frequency distribution based on credit goal.

Table 1. Crop production elasticities (Kilograms per Hectare).

\begin{tabular}{cccc}
\hline Variables & Coefficients & t-values & Probability \\
\hline (Constant) & 10.18 & 8.55 & 0.00 \\
$X_{1}$ Manure cost & -0.09 & -3.88 & 0.00 \\
$x_{2}$ Regression cost & 0.01 & 0.09 & 0.93 \\
$X_{3}$ Plant shield cost & 0.16 & 1.68 & 0.09 \\
$X_{4}$ Land preparation cost & 0.01 & 0.16 & 0.87 \\
$x_{5}$ Dummy variable & 0.05 & 2.04 & 0.04 \\
(credit users1 and 0 alternatively) & 0.45 & F-Statistics & 4.21 \\
R-Squared & &
\end{tabular}

Note: All variables are in $\log$ form with the exception of $X 5$. The attribute depends upon the production of wheat per hectare in kilograms.

\section{Findings and Suggestions}

The conclusion can be drawn that the loan has a favorable impact on the productivity of wheat crops, which therefore increases rural poor living standards. Nonetheless, the credit coefficient is small as primary analysis shows that only $30 \%$ of credit users used loans for the use of seeds and fertilizer compared with $70 \%$ used loans for other purposes. The results indicate that production growth due to the use of credit has risen by 5 percent. The policy implications of this study are significant, based on findings that wheat productivity can be enhanced more if farmers use credit for the production of wheat instead of marriages and other activities. It is also noted that $80 \%$ of credit users have been borrowed from ZTBL. In the past, ZTBL was a significant source of loans. ZTBL will award farmers credit in accordance with their requirements and crop value. It should be easy to recover the credit. The study suggests that financial institutions should ensure that loans are used solely for farming purposes. The media should be employed to raise awareness of the crucial role of credit in agricultural pro- 
duction for farmers. New and specialized banks should be set up to provide farmers with fast farm loans. The results of this study reflect that agricultural credit has a significant positive effect on cereal productivity in the Sargodha district of Punjab.

\section{Conflicts of Interest}

The authors declare no conflicts of interest regarding the publication of this paper.

\section{References}

Bashir, M., Ahmad, K., \& Hassan S. (2010). Impact of Credit Disbursed by Commercial Banks on the Productivity of Wheat in Lahore District. Pakistan Journal of Agricultural Sciences, 47, 405-409.

Bhanumurthy, K. V. (2002). Arguing a Case for the Cobb-Douglas Production Function (pp. 75-91). Review of Communication Studies, Delhi, India.

Government of Pakistan (GOP) (2018a). Agricultural Statistics of Pakistan. Islamabad: Ministry of Food, Agricultural and Livestock.

Government of Pakistan (GOP) (2018b). Economic Survey of Pakistan. Islamabad: Ministry of Finance.

Iqbal, M., Ahmad, M., \& Abbas, K. (2003). The Impact of Institutional Credit on Agricultural Production in Pakistan. The Pakistan Development Review, 42, 469-485.

https://doi.org/10.30541/v42i4IIpp.469-485

Jan, I., Munir, S., Usman, A., \& Idress, M. (2012). Agricultural Credit Markets in North-West Pakistan: Implications for the Development Policy. Sarhad Journal of Agriculture, 28, 521-529.

Machete, L. (2004). Agriculture and Poverty in South Africa: Agriculture Can Reduce Poverty? Pretoria, South Africa: Paper Presented at the Overcoming Underdevelopment Conference.

Okurut, F. N., Banga, M., \& Mukungu, A. (2004). Micro Finance and Poverty Reduction, UGAN-DA: Achievements and Challenges. Research Series No. 41. Kampala: Economic Policy Research Centre EPRC, Makerere University.

Sebopetji, T. O., \& Belete, A. (2009). An Application of Probit Analysis to Factors Affecting Small-Scale Farmers' Decision to Take Credit: A Case Study of the Greater Letaba Local Municipality in South Africa. African Journal of Agricultural Research, 4, 718-723. 